Article

\title{
Adoption of Grid-Tie Solar System at Residential Scale
}

\author{
Aneesh A. Chand *, Kushal A. Prasad, Kabir A. Mamun, Krishneel R. Sharma and \\ Kritish K. Chand
}

School of Engineering and Physics, The University of the South Pacific, Suva, Fiji

* Correspondence: aneeshamitesh@gmail.com or aneesh.chand@usp.ac.fj; Tel.: +6799321994

Received: 13 May 2019; Accepted: 6 August 2019; Published: 8 August 2019

\begin{abstract}
Traditionally, remote and urban communities worldwide have been supplied electricity almost completely by fossil fuel generators to accommodate for electricity needs. Currently, the integration of renewable energy sources (RESs) into the current power generation systems can offer attractive economic and environmental merits, including considerable fuel savings and carbon dioxide emission reductions. In relation to sustainability, efficiency and economic feasibility, solar photovoltaic (PV) is one of the most promising sources of RESs which is being touted as a leading solution to long-term electrification and development problems in rural and urban parts of Pacific Island Countries (PICs). In this work, a grid-tie PV system is instigated at a residential scale. The idea of this research is not to claim the power output from the PV system but to show the feasibility of a grid-tie system at a residential scale. This will help the PICs, non-profit organisations and the government better share scarce resources towards achieving their energy goals and be in line with Sustainable Development Goal (SDG) 7, ensuring access to affordable, reliable, sustainable and modern energy for all.
\end{abstract}

Keywords: renewable energy sources (RESs); Pacific Island Countries (PICs); grid-tie; Sustainable Development Goal (SDG)

\section{Introduction}

The acceptance of photovoltaic (PV) installations has grown rapidly in the Pacific Island Countries (PICs), hence creating rural electrification and leading to sustainable development with renewable energy sources (RESs) [1-3]. Also, the increased use of fossil fuel-based electricity in the PICs is not only increasing the carbon footprint, but is also affecting the people's health. However, they suffer from the dual challenge of inadequate access to modern energy services, resulting in a high dependency on imported fossil fuels [4-6]. Fiji is one of the developing states, consisting of over 300 small islands, and has a population of almost 900,000 and growing [1]. Fiji's energy supply is around 296 megawatts, of which 254 megawatts is grid-connected as of 2015 [2]. Being a small island nation, Fiji is heavily dependent on imported fossil fuels for its energy needs, although $55 \%$ of its energy production is from RESs [1-3]. Nearly $4 \%$ of urban and $20 \%$ of rural areas lack electricity [1]. Fiji is on a mission to have $100 \%$ renewable energy by the year 2030 [4], which is in conjunction with Sustainable Development Goal (SDG) 7. Therefore, the government has recognised the goal to "act now to reduce the reliance on imported fossil fuels through renewable energy while increasing the use efficiency of current fossil fuel supplies" in the national energy policy [3].

RESs have offered viable solutions for remote area electrification. Solar irradiation is free and clean, yet harvesting useful energy is challenging $[7,8]$. PV is the most favorable RES for numerous industrial and domestic applications. Consideration of home energy management systems (HEMS) as a way to reduce greenhouse gas emissions and to allow the automatic management of electricity in 
households enhances the effectiveness of renewable energy. The use of solar energy is more closely associated with increased technological advancement, such as television use, expansion of markets, rural-urban communication or connectivity, sustainable development and increased energy use.

Grid-tie solar systems are a better option as they do not require expensive energy storage systems [9]. This system can be easily installed in existing home power networks to power appliances throughout the day. Compared to conventional stand-alone solar systems, the grid-tie delivers more power as the losses in charging, battery losses and inverting losses are eliminated [9-11]. Cost is also reduced hugely as maintenance is minimal due to the elimination of storage units.

In this research, we explore the use of the grid-tie solar system with the purpose of maximising the economic benefit by using this system at a residential scale that is, reducing the cost of the purchased energy from the grid whilst satisfying the load demand.

The structure of the paper is as follows: In Section 2, a brief overview of the concept design and system integration is demonstrated. In Section 3, a case study is shown, and system architecture is presented in Section 4. Subsequently, Section 5 shows the economic analysis of the grid-tie solar system. Finally, in Sections 5 and 6, the most important limitation and benefits of the grid-tie solar system and the conclusion of the research, respectively, are presented.

\section{Concept Design and System Integration}

Climate change is a concern due to the rising amount of carbon gases in the atmosphere over the past few centuries. This initiated a fast pace of technological advancements in the renewable energy industry to help curb the situation [11-13]. Solar power is green, environmentally friendly and PV systems have become a sustainable option for isolated locations receiving abundant sunshine, which aligns with PICs. The PV is able to effectively convert solar radiation into a direct current through the occurrence of the PV effect in semiconductors enabling the flow of electrons, thus generating electricity.

Nowadays, rural home lighting is mostly powered by PV systems known as stand-alone solar systems, as illustrated in Figure 1, which is more relevant for PICs [14-17]. The most classical configuration layout of a grid-connected PV system is shown in Figure 2.

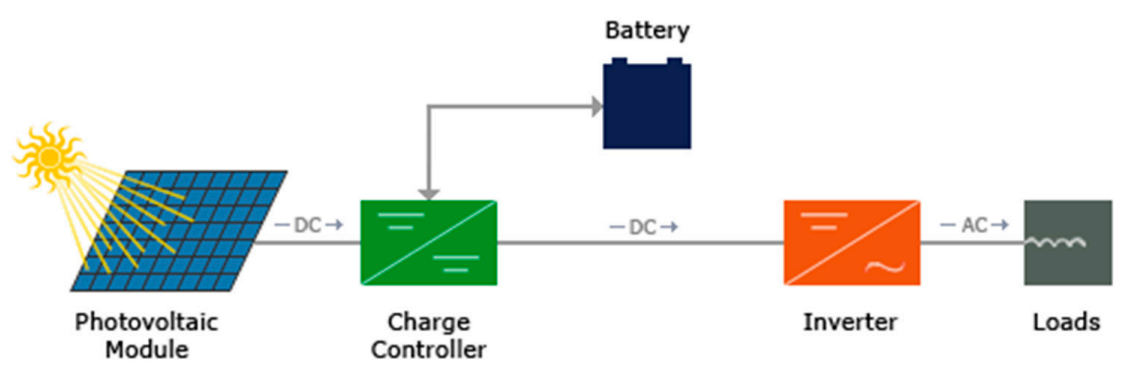

Figure 1. Classical configuration layout of stand-alone system.

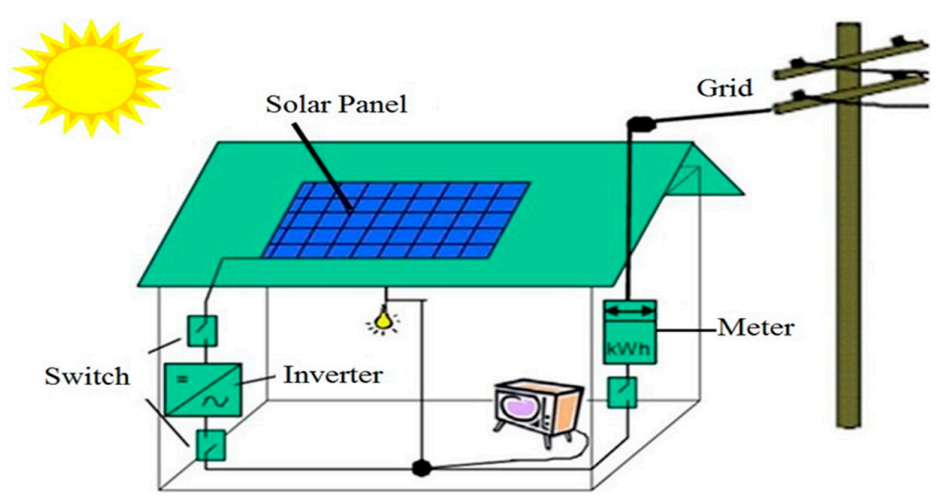

Figure 2. Classical configuration layout for grid-tie system. 
Currently, the commercialised grid-connected system for a household based on the classical configuration stand-alone system is quite expensive as it consists of more components. The components are PV cells, charge controllers, battery packs and converting devices, which make it expensive compared to the grid-connected system, as it comprises the PV cells and a grid-tie converter [1-4,14-18]. Thus, having a grid-tie solar system for a household is cheaper in terms of capital cost and installation.

The most renowned jargon used in the solar industry are solar radiation and solar irradiance. The total radiant energy emitted by the sun is called solar radiation, whereas the power per unit area received from the sun in the form of electromagnetic radiation measured in space or at the Earth's surface is called solar irradiance [16]. To obtain the optimal amount of energy from the PV system, solar radiation analysis is a very important factor that needs to be considered. Solar radiation patterns are required for any PV system. Validating all the monthly solar radiation in $\mathrm{kWh} / \mathrm{m}^{2} /$ day are obtained from the available NASA data for 2015, as created by RETScreen@, as shown in Figure 3.

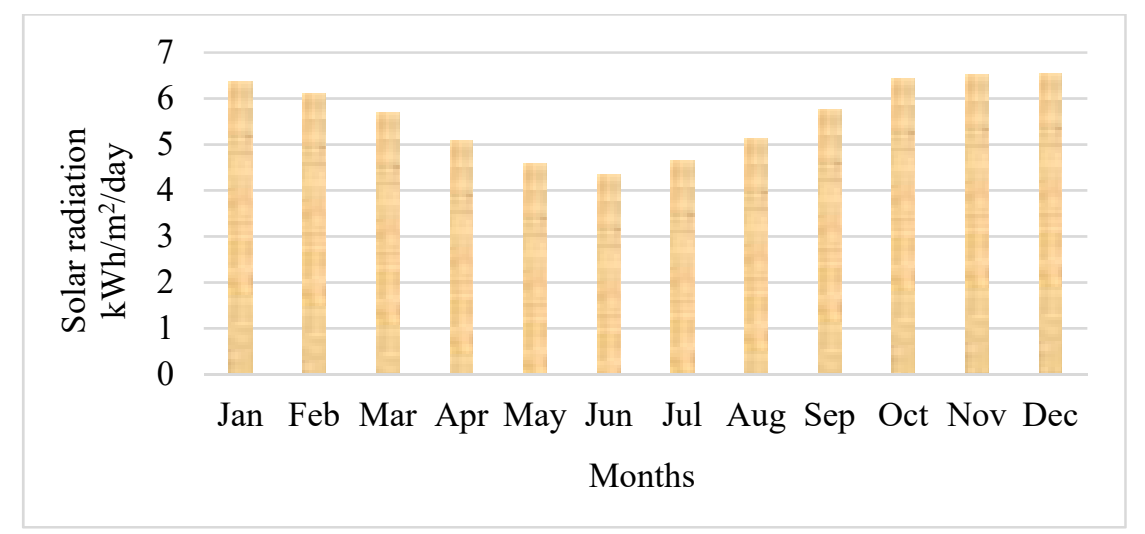

Figure 3. Solar radiation [16].

\section{Case Study}

The study area of this paper was in Suva, Fiji, situated between latitude -18.14 and longitude 178.44. This work presents a solar home grid-tie system used for supplying power to a household during the day. Load analysis is vital when installing solar power in a household. The average energy consumption of a household is influenced by many factors, like the construction and size of the house, climate, season and members in a family [15]. The typical house load is comprised of mainly lighting load, TV, refrigerator and a radio (see Table 1). Energy Fiji Limited (EFL) is the only established utility grid in Fiji, which supplies power for the whole of Fiji at a rate of 0.331 FJD (Fijian Dollar) per kW [2]. 1 FJD is equal to 0.46 USD (United State Dollar).

Table 1. Typical household load profile for the chosen house during the day.

\begin{tabular}{ccccc}
\hline Loads & Energy (kWh) Consumption & Quantity & Hours Used & Total Load (kWh) \\
\hline Lights 1 & 0.02 & 2 & 3 & 0.04 \\
TV & 0.1 & 1 & 2 & 0.1 \\
Phone charger & 0.012 & 2 & 2.5 & 0.06 \\
Refrigerator & 0.05 & 2 & 10 & 0.5 \\
Others & 0.1 & 1 & 2 & 0.2 \\
\hline
\end{tabular}

The grid-tie solar system was chosen such that it did not feed back to the grid but allowed solar to supplement the load requirements. A suitable-sized system was needed, thus a load analysis was done to gauge the maximum consumption during the day and supplement as much as possible to rely less on the grid supply. A load such as a refrigerator has an average power consumption of $0.05 \mathrm{kWh}-0.1 \mathrm{kWh}$, but it may consume much more power as it works on certain intervals. For this 
household, a $0.65 \mathrm{~kW}$ PV module was used with a $0.6 \mathrm{~kW}$ grid-tie inverter system to accommodate the load during the day.

\section{Architecture of the System}

Solar energy is the most promising RES in view of its apparent potential. Grid-tie solar PV systems have become widespread in both developed and developing countries $[1,3,5,13,15,19]$. A grid-tie solar energy system was designed using a solar panel, control unit and DC/AC converter, as shown in Figure 4 . The grid-tie inverter works when the PV receives enough sunlight, generating DC voltage. The varying DC voltage is regulated by the DC/DC converter and converted to AC voltage via an inverter. The inverted voltage that has to be put into the grid has to be of the same characteristics as the grid in terms of voltage and frequency. This is accomplished through a comparator circuit responsible for monitoring the grid supply parameters and adjusting the output of the grid-tie inverter to effectively synchronise with the grid. All functions are performed by a grid-tie inverter, which makes the system efficient and feasible.

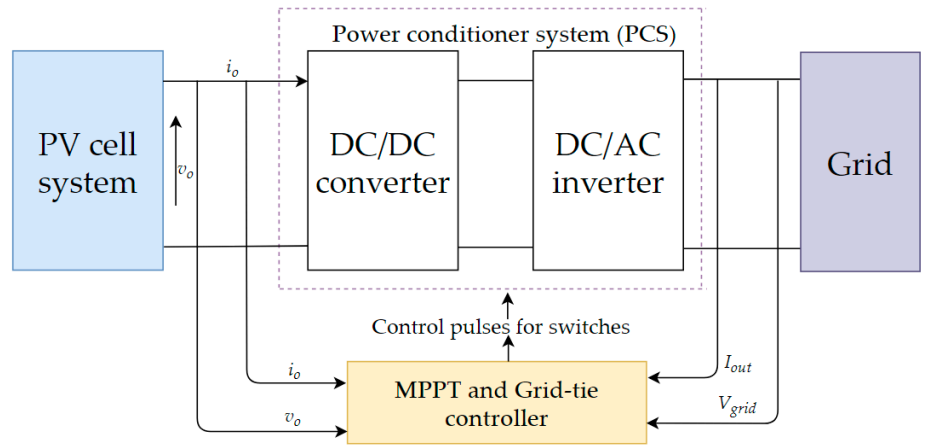

Figure 4. Grid-tie/MPPT control algorithm.

\subsection{Solar Modules}

Solar modules or PV panels generate power which is DC, thus an inverter was utilised to convert the $\mathrm{DC}$ to $\mathrm{AC}$ to match the appliance needs. Using this energy during the night is possible through employing a storage mechanism such as a battery, which usually has a large storage capacity for this type of situation [3,9]. Basic components of solar systems include PV modules, battery banks or storage units, controllers and converters and circuitry essentials to work efficiently.

The solar insolation, or the amount of sunlight incident on a surface, is the critical part as it directly affects the power output of the PV unit. This is dependent upon the sunlight's declination angle $(\theta)$ of the location $(\varphi)$ on earth's latitude and the PV unit's tilt angle $(\vartheta)$ with reference to the horizon $[3,20]$. Throughout the year, the declination angle changes, given by Equation (1), between $+23.45^{\circ}$ to $-23.45^{\circ}$, where the nth day of the year, beginning from 1 January, is represented by $n$.

$$
\delta=23.45 \sin \left[\frac{360}{365}(284+n)\right](\text { in degree })
$$

To harness the maximum energy from the panels, the tilt angle or angle of inclination has to be varied throughout the year. Sun tracking devices have been developed and utilised to enhance the generation capacity, but these devices incur huge additional costs, making it economically not feasible.

\subsection{Maximum Power Point Tracking (MPPT)}

A MPPT is an electronic device (DC to DC converter) that is responsible for optimising the system voltage to provide a match between the solar panels and utility grid or battery packs. This is enabled through embedded systems in electronics, usually digital, that take the DC input from the panels, changing it to high frequency AC and converting it back to the desired DC voltage. The MPPT 
controller compares the output of the panels with the battery voltage to efficiently output the power of the panels to charge the battery with maximum amps $[3,9,19]$.

\subsection{Grid-Tie Inverter}

Grid-connected solar systems require a special device known as a grid-tie inverter to deliver power to the grid. This device converts the DC voltage produced by the PV panels to grid-compatible sinusoidal AC voltage output in order to synchronise with the grid. The grid-tie inverter monitors the grid supply characteristics, which are voltage and frequency, and adjusts the output accordingly to match the grid $[9,10,14,18,21]$. A grid-connected solar system works only if the grid is online, that is, if the grid shuts down, the system will no longer provide power supply.

\section{Economic Analysis}

As mentioned earlier, the most accepted configuration of PV systems are stand-alone and grid-tie. Both have their own benefits and drawbacks. Table 2 shows the initial cost comparison of the two types of the system as per the load analyses in the case study. Most of the stand-alone systems are designed taking into consideration two to four days' autonomy to compensate for weather fluctuations and for this case study we have chosen two days. The stand-alone system was designed to cater for $10 \mathrm{~h}$ during the day only as the grid-tie system works approximately $10 \mathrm{~h}$ during the day.

Table 2. Initial cost comparison of grid-tie and stand-alone systems with different autonomy.

\begin{tabular}{|c|c|c|c|c|c|c|}
\hline \multirow{3}{*}{$\begin{array}{c}\text { Item } \\
\text { Equipment }\end{array}$} & \multirow{2}{*}{\multicolumn{2}{|c|}{ Grid-Tie }} & \multicolumn{4}{|c|}{ Stand-Alone } \\
\hline & & & \multicolumn{2}{|c|}{1 Day Autonomy } & \multicolumn{2}{|c|}{2 Day Autonomy } \\
\hline & Quantity & Cost FJD & Quantity & Cost FJD & Quantity & Cost FJD \\
\hline PV panel & $325 \mathrm{~W} \times 2$ & 800 & $325 \mathrm{~W} \times 1$ & 400 & $325 \mathrm{~W} \times 2$ & 800 \\
\hline Inverter & $\begin{array}{c}600 \mathrm{~W} \\
\text { (Grid-tie) }\end{array}$ & 200 & $600 \mathrm{~W} \times 1$ & 400 & $600 \mathrm{~W}$ & 400 \\
\hline Batteries & - & - & $12 \mathrm{~V} \times 100 \mathrm{Ah}$ & 400 & $12 \mathrm{~V} \times 100 \mathrm{Ah} \times 2$ & 800 \\
\hline MPPT & - & - & 1 & 200 & 1 & 200 \\
\hline Total & - & 1000 & - & 1400 & - & 2200 \\
\hline
\end{tabular}

The economic value of adding solar PV is based on changes in the total annual $\mathrm{kWh}$ consumption and costs. Analysis was carried out on three years of kWh data to see the feasible effect of installing the grid-tie PV energy system [2,14]. The recorded information clearly shows, as shown in Figure 5, the effectiveness of the grid-tie system. The monthly energy consumption was compared for the last three years. It was seen that energy consumption from the grid was much less in 2018 as it was supplemented by the grid-tie system. It is evident that an average of about $20 \mathrm{kWh}$ was supplemented through solar grid-tie system, saving almost 6.62 FJD. The return on investment of the proposed system was around 13 years with an initial investment of 1000 FJD.

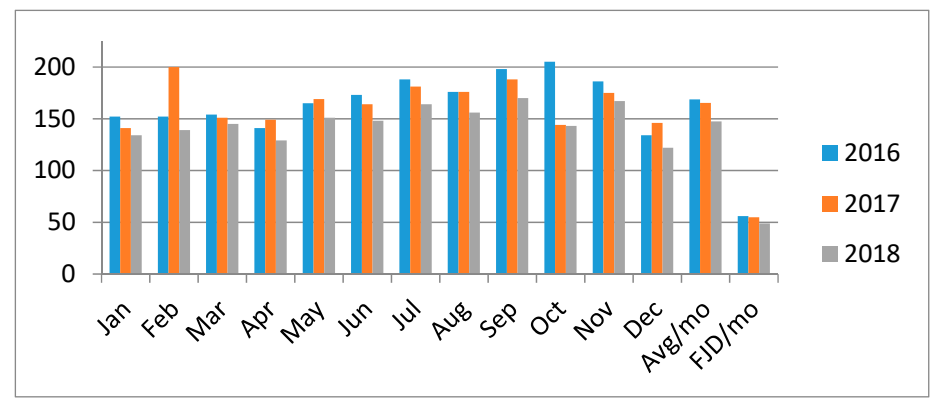

Figure 5. Energy consumption from the grid for the past three years. A sample of a bill is attached in Appendix A. 
On the other hand, the maintenance cost for the proposed system is less compared to stand-alone configuration. Table 3 summarises the maintenance periods for two different PV systems. The grid-tie system has less maintenance as it has no storage unit, thus no maintenance and replacements, which on the other hand is an additional cost in the stand-alone system due to a short battery life span. This makes the grid-tie system stand out in terms of installation and maintenance cost.

Table 3. Maintenance schedule for grid-tie and stand-alone systems.

\begin{tabular}{ccc}
\hline Schedules & Grid-Tie & Stand-Alone \\
\hline PV life span & $15-25$ years & $15-25$ years \\
PV maintenance (clean) & Annually & Annually \\
Invertor life & $10-20$ years & $10-20$ years \\
Battery life & - & $5-10$ years \\
Battery maintenance & - & Annually \\
\hline
\end{tabular}

\section{Limitation and Benefits of Grid-Tie Solar System}

Solar energy is considered as supreme in renewable energy technology as it requires only sunlight to produce electrical energy. The segmental design enables it to be very flexible in terms of reconfiguration and adapting to demand changes for other applications as the grid-tie systems eliminate the use of batteries and controllers. The elimination of some components reduces the maintenance required to almost zero.

The foremost benefit of having a grid-tie solar energy system is that it is cheap when compared to an off-grid solar energy system. This is due to the fact that it does not require battery storage systems to store energy as it directly delivers the energy from sunlight into the grid.

The grid-tie inverter converts DC energy to AC and feeds it into the grid, reducing dependence on power supplied by the grid. These results in the reduction of purchased energy from the grid thus relish the energy at a lower cost.

Solar energy is available in abundance and utilising this energy not only saves electricity costs, but also endorses the use of green energy. The proclivity towards the sun's energy enhances the socio-economic prosperity of companies, societies and nations.

Though grid-tie systems are gaining popularity, there are a few inevitable limitations associated with this type of system. The energy supply from the PV panels is only available during the day, thus there is a dependence on grid supply during no-sun hours as storage systems are eliminated. Yet this limitation is not sufficient to restrict the use of these grid-tie systems.

\section{Conclusions}

Solar home energy systems play a dynamic role in bringing renewable and sustainable development to communities in PICs. In this work, a grid-tie PV system was connected to a residential home to assess the feasibility of the system. The result of the overall system was impressive as it was able to reduce the monthly dependence on the grid by almost $20 \mathrm{kWh}$, which equates to 6.62 FJD per month. The return on investment period was 13 years, which is very impressive as it supplemented the household load without selling to the grid. The research findings depicted clearly that using a grid-tie system is cost effective in the long run, although initial costs are high, but not as high as stand-alone systems. The maintenance cost is heavily reduced in contrast with the stand-alone type systems. The addition of renewable energy components, though at a residential scale, equates to greenhouse gas reduction and moves towards SDG 7, ensuring access to affordable, reliable, sustainable and modern energy for all.

Author Contributions: Conceptualisation, K.A.P. and A.A.C.; methodology, K.A.P.; validation, A.A.C., K.R.S. and K.A.M.; formal analysis, K.A.P.; investigation, K.A.P.; resources, K.A.M.; data curation, K.K.C.; writing-original draft preparation, A.A.C.; writing-review and editing, A.A.C. 
Funding: This research project was not funded by any other external body, but the authors have personally funded the project for completion.

Acknowledgments: The authors would like to acknowledge the research student at The University of the South Pacific (USP) for the completion of this project.

Conflicts of Interest: The authors declare no conflict of interest.

\section{Abbreviations}

$\begin{array}{ll}\text { AC } & \text { Alternating Current } \\ \text { DC } & \text { Direct Current } \\ \text { PV } & \text { Photovoltaic } \\ \text { PICs } & \text { Pacific Islands Countries } \\ \text { RESs } & \text { Renewable Energy Sources } \\ \text { HEMS } & \text { Home Energy Management Systems } \\ \text { MPPT } & \text { Maximum Power Point Tracking } \\ \text { kWh } & \text { kilowatt hour }\end{array}$

\section{Appendix A}

The data represented under Economic Analysis was available from an electrical utility bill for three years and is shown in Figure 4. A sample of an electrical utility bill is shown in this section for Data Availability verification.
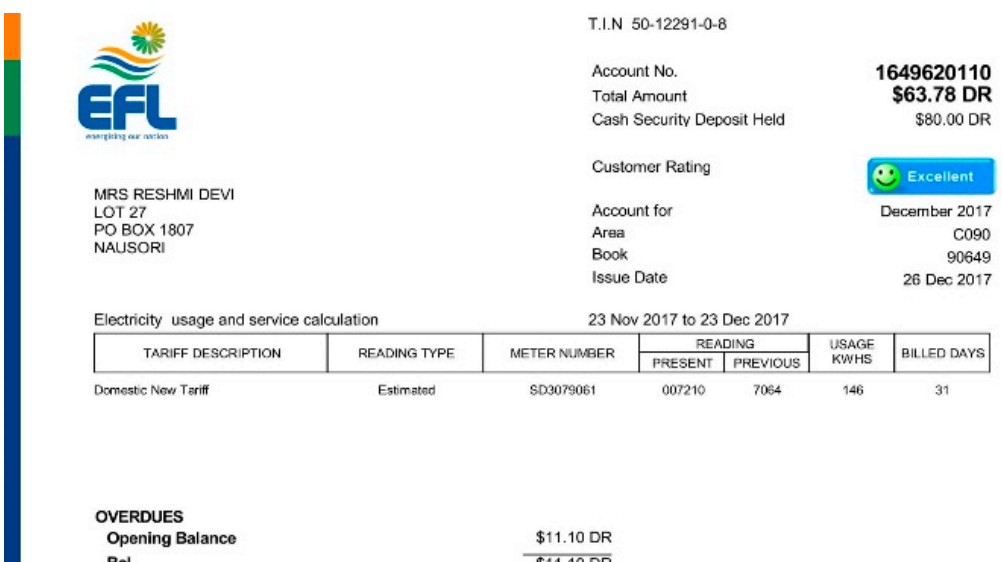

Bal

$\$ 11.10 \mathrm{DR}$

CURRENT CHARGES

CURRENT USAGE

Current Usage

$146 \mathrm{KWH} @ \$ 0.3$

OTHER SERVICES

Other Services

Total Current Charges Due (VEP)

Total Current Charges Due (VIP)

TOTAL DUE

CURRENT PAYMENT DUE BEFORE 09 Jan 2018

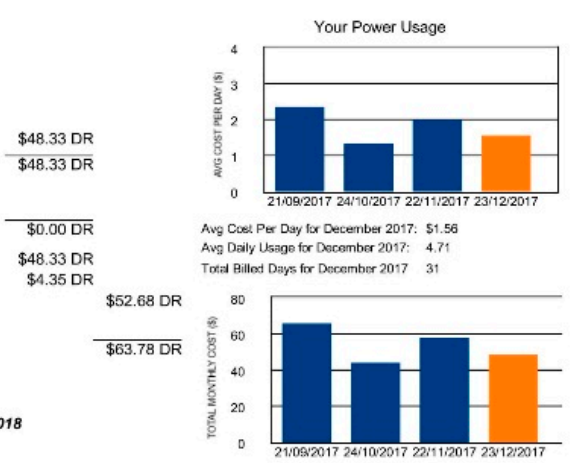

Figure A1. A sample of electrical utility bill in Fiji. 


\section{References}

1. Prasad, R.D.; Raturi, A. Grid electricity for Fiji islands: Future supply options and assessment of demand trends. Energy 2017, 119, 860-871. [CrossRef]

2. Lal, S.; Raturi, A. Techno-economic analysis of a hybrid mini-grid system for Fiji islands. Int. J. Energy Environ. Eng. 2012, 10, 3. [CrossRef]

3. Raturi, A.; Singh, A.; Prasad, R.D. Grid-connected PV systems in the Pacific Island Countries. Renew. Sustain. Energy Rev. 2016, 58, 419-428. [CrossRef]

4. Islam, F.R.; Mamun, K.A. Possibilities and Challenges of Implementing Renewable Energy in the Light of PESTLE \& SWOT Analyses for Island Countries. In Smart Energy Grid Design for Island Countries; Springer: Cham, Germany, 2017; pp. 1-19.

5. Chand, S.S.; Iqbal, A.; Cirrincione, M.; Islam, F.R.; Mamun, K.A.; Kumar, A. Identifying Energy Trends in Fiji Islands. In Smart Energy Grid Design for Island Countries; Springer: Cham, Germany, 2017; pp. 259-287.

6. Prakash, S.S.; Mamun, K.A.; Islam, F.R.; Cirrincione, M. Design of a Hybrid Microgrid for a Rural Community in Pacific Island Countries. In Proceedings of the 2017 4th Asia-Pacific World Congress on Computer Science and Engineering (APWC on CSE), Nadi, Fiji, 11-13 December 2017; pp. 246-251.

7. Panwar, N.L.; Kaushik, S.C.; Kothari, S. Role of renewable energy sources in environmental protection: A review. Renew. Sustain. Energy Rev. 2011, 15, 1513-1524. [CrossRef]

8. Prakash, K.; Islam, F.R.; Mamun, K.A.; Lallu, A.; Cirrincione, M. Reliability of Power Distribution Networks with Renewable Energy Sources. In Proceedings of the 2017 4th Asia-Pacific World Congress on Computer Science and Engineering (APWC on CSE), Nadi, Fiji, 11-13 December 2017; pp. 187-192.

9. Mensah, L.D.; John, O.Y.; Muyiwa, S.A. Performance evaluation of a utility-scale grid-tied solar photovoltaic (PV) installation in Ghana. Energy Sustain. Dev. 2019, 48, 82-87. [CrossRef]

10. Huang, X.; Wang, K.; Fan, B.; Yang, Q.; Li, G.J.; Xie, D.; Crow, L.M. Robust Current Control of Grid-tied Inverters for Renewable Energy Integration under Non-Ideal Grid Conditions. IEEE Trans. Sustain. Energy 2019, 1-12. [CrossRef]

11. Islam, F.R.; Mamun, K.A.; Amanullah, M.T.O. Smart Energy Grid Design for Island Countries: Challenges and Opportunities; Springer: Berlin, Germany, 2017; pp. 1-12.

12. Islam, F.R.; Prakash, K.; Mamun, K.A.; Lallu, A.; Pota, H.R. Aromatic network: A novel structure for power distribution system. IEEE Access 2017, 5, 25236-25257. [CrossRef]

13. Islam, F.R.; Mamun, K.A. Reliability evaluation of power network: A case study of Fiji Islands. In Proceedings of the Australasian universities power engineering conference (AUPEC-2016), Brisbane, Australia, 25-28 September 2016.

14. Nand, R.T.; Raturi, A. Feasibility study of a grid connected photovoltaic system for the central region of Fiji. Appl. Sol. Energy 2013, 49, 2110-2115. [CrossRef]

15. Prasad, R.D.; Bansal, R.C.; Raturi, A. A review of Fiji's energy situation: Challenges and strategies as a small island developing state. Renew. Sustain. Energy Rev. 2017, 75, 278-292. [CrossRef]

16. Aitchison, D.; Cirrincione, M.; Cirrincione, G.; Mohammadi, A.; Pucci, M. Feasibility Study and Design of a Flywheel Energy System in a Microgrid for Small Village in Pacific Island State Countries. In Smart Energy Grid Design for Island Countries; Springer: Cham, Germany, 2017; pp. 159-187.

17. Phap, V.M.; Yamamura, N.; Ishida, M.; Hirai, J.; Yubai, K.; Nga, N.T. Modeling and Experimental Test of Grid-Tied Photovoltaic Cell Emulating System in the Stand-alone Mode. J. Electr. Syst. 2017, 13, 2.

18. Yadav, A.K.; Chandel, S.S. Tilt angle optimization to maximize incident solar radiation: A review. Renew. Sustain. Energy Rev. 2013, 23, 503-513. [CrossRef]

19. Islam, F.R.; Prakash, K.; Mamun, K.A.; Lallu, A.; Mudliar, R.R. Design of an optimum MPPT controller for solar energy system. Indones. J. Electr. Eng. Comput. Sci. 2016, 2, 545-553. [CrossRef]

20. Subramani, G.; Ramachandaramurthy, V.K.; Padmanaban, S.; Mihet-Popa, L.; Blaabjerg, F.; Guerrero, J.M. Grid-tied photovoltaic and battery storage systems with Malaysian electricity tariff-A review on maximum demand shaving. Energies 2017, 10, 1884. [CrossRef] 
21. Zhai, Q.; Cao, H.; Zhao, X.; Yuan, C. Cost benefit analysis of using clean energy supplies to reduce greenhouse gas emissions of global automotive manufacturing. Energies 2011, 4, 1478-1494. [CrossRef]

(C) 2019 by the authors. Licensee MDPI, Basel, Switzerland. This article is an open access article distributed under the terms and conditions of the Creative Commons Attribution (CC BY) license (http://creativecommons.org/licenses/by/4.0/). 